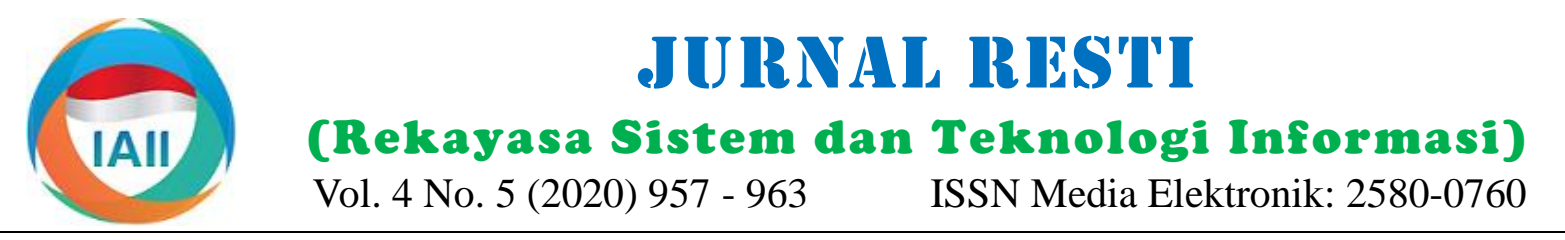

\title{
Implementasi Algoritma Improvised Prioritized Deadline Scheduling Algorithm (IPDSA) pada Grid Environment Menggunakan PVM3
}

\author{
Haidar Hendri Setyawan ${ }^{1}$, Wisnu Widiarto ${ }^{2}$, Ardhi Wijayanto ${ }^{3}$ \\ ${ }^{123}$ Informatika, Universitas Sebelas Maret Surakarta \\ ${ }^{1}$ haidarhendri@student.uns.ac.id, ${ }^{2}$ wisnu.widiarto@staff.uns.ac.id*, ${ }^{3}$ ardhi.wijayanto@staff.uns.ac.id
}

\begin{abstract}
Resource Scheduling is one of the most challenging parts of grid computing. A number of algorithms have been designed and developed to create effective resource scheduling. In this research, the algorithms that have been used are the improvised prioritized deadline scheduling algorithm (IPDSA), and the parallel virtual machine version 3 (PVM3) has been used for efficient task execution, with a deadline limit for each task. PVM3 is a software library that optimizes resources flexibly and heterogeneously on a computer. These resources have been connected to various architectures in parallel, so that they can complete tasks well, even though they are very large and complex. This research has implemented the IPDSA resource scheduling algorithm to optimize scheduling and Grid resources in a computer laboratory as a grid environment, where the computers (hosts) are the Grid resource. This research has also developed an IPDSA resource scheduling algorithm by giving priority to each task and implemented using PVM3. The IPDSA resource scheduling algorithm has been successfully implemented using PVM3, with average Tardiness showing a stable value and getting a Non-Delayed Task value above $97.3 \%$, because the resources and tasks that are carried out can be distributed evenly according to the number of hosts used.
\end{abstract}

Keywords: Grid Computing, Resource Scheduling, Two-level Hierarchy Scheduling Model, PVM3, IPDSA

\begin{abstract}
Abstrak
Resource Scheduling adalah salah satu bagian yang menantang dalam komputasi grid. Sejumlah algoritma telah dirancang dan dikembangkan untuk membuat resource scheduling yang efektif. Dalam riset ini, algoritma yang telah digunakan adalah algoritma improvised prioritized deadline scheduling algorithm (IPDSA), dan parallel virtual machine versi 3 (PVM3) telah digunakan untuk eksekusi task yang efisien, dengan batasan deadline dari setiap task. PVM3 merupakan library perangkat lunak yang mengoptimalkan sumber daya secara fleksibel dan heterogen pada komputer. Sumber daya tersebut telah saling terhubung dengan beragam arsitektur secara paralel, sehingga telah dapat menyelesaikan tasks dengan baik, meskipun berukuran sangat besar dan kompleks. Riset ini telah mengimplementasikan algoritma resource scheduling IPDSA untuk mengoptimalkan penjadwalan dan sumber daya Grid pada suatu laboratorium komputer sebagai grid environment, dimana komputer - komputer (hosts) tersebut sebagai sumber daya Grid. Penelitian ini juga telah mengembangkan algoritma resource scheduling IPDSA dengan memberikan prioritas pada setiap task dan diimplementasikan menggunakan PVM3. Algoritma resource scheduling IPDSA telah berhasil diimplementasikan menggunakan PVM3, dengan Tardiness rata-rata menunjukkan nilai yang stabil dan mendapatkan nilai Non-Delayed Task diatas 97,3\%, karena sumber daya dan task yang dikerjakan dapat didistribusikan secara merata sesuai dengan jumlah host yang digunakan.
\end{abstract}

Kata kunci: Grid Computing, Resource Scheduling, Two-level Hierarchy Scheduling Model, PVM3, IPDSA

\section{Pendahuluan}

Grid merupakan suatu sumber daya komputer yang saling terhubung dan tersebar untuk mendistribusikan suatu layanan kepada pengguna. Komputasi pada grid pada dasarnya digunakan untuk mengkombinasikan kemampuan, bandwidth komunikasi dan kapasitas pemrosesan yang dapat bervariasi dalam sebuah sistem yang ada pada grid $[1,2,3]$. Semakin besarnya kebutuhan penggunaan teknologi informasi dan komunikasi dalam kehidupan sehari-hari membuat beban komputasi semakin besar. Hal ini diakibatkan oleh task atau tugas yang semakin banyak dan kompleks karena kebutuhan pengguna yang sangat tinggi dan dinamis. Karena keterbatasan resourece atau sumber daya komputasi yang dimiiliki, perusahaan mengandalkan teknologi komputasi grid untuk meninggatkan kualitas pelayanan

Diterima Redaksi: 10-09-2020 | Selesai Revisi : 18-10-2020 | Diterbitkan Online : 30-10-2020 
dan menyelesaikan kebutuhan komputasi mereka $[4,5,6]$.

Salah satu bagian dari komputasi Grid adalah resource scheduling [7]. Resource scheduling merupakan cara untuk menentukan task mana yang harus dikerjakan dan memilih resource untuk mengerjakan task tersebut berdasarkan pada parameter Quality of Service (QoS) Pada penelitian ini dilakukan percobaan dengan jumlah yang dibutuhkan. Bagian ini merupakan salah satu host yang beragam, yaitu 7 host, 10 host, 15 host, 25 bagian terpenting pada grid, karena bertanggung jawab host, 27 host, 30 host, 33 host dan 40 host, berdasarkan untuk memilih virtual machine yang optimal untuk sumber daya yang digunakan dengan jumlah dan melaksanakan tugas menggunakan algoritma resource spesifikasi sumber daya yang heterogen dan kondisi scheduling dan bertanggung jawab untuk memeriksa yang berbeda.

apakah ada kendala dalam memenuhi QoS.

Terdapat beberapa algoritma resource scheduling yang digunakan pada penelitian in terbagi menjadi 3 (tiga) skema, yaitu heuristic scheduling IPDSA dan PVM3 (Parallel Virtual scheduling, meta-heuristic scheduling, dan hybrid Machine versi 3).

scheduling. Algoritma dari masing-masing skema tersebut diataranya Round Robin, First Come First Serve (FCFS), Deadline Constraint based, QoS based, Algoritma Resource Scheduling IPDSA (Improvised Artificial Honey Bee, Genetic Algorthm, ACO+Max-min Prioritized Deadline Scheduling Algorithm) [8]. Setiap algoritma memiliki kekurangan dan dikembangkan oleh Anubha Chauhan [11]. Model kelebihan masing-masing yang digunakan untuk resource scheduling pada algoritma IPDSA pada menyelesaikan masalah tertentu dan hasil yang efisien langkah awal mengumpulkan resource kedalam sebuah dan optimal.

Penelitian-penelitian untuk menentukan resource scheduling telah banyak dilakukan, yaitu membandingan sebuah algoritma resource scheduling dan mengembangkannya serta membandingkan algoritma tersebut dengan algoritma-algoritma lainnya dengan mengujinya pada suatu perangkat simulasi. Perangkat simulasi yang banyak digunakan peneliti adalah CloudSim atau GridSim [9]. Mengembangkan algoritma resource scheduling dengan pendekatan pada perilaku semut yang mencari makanan dan diberi nama Ant Algorithm-based [10]. Mengembangkan Algoritma Prioritized Deadline Scheduling Algorithm (PDSA) dan Earlier Deadline First (EDF) dengan pendekatan pada batas tenggat waktu pekerjaan untuk dieksekusi yang diberi nama Improvisied Prioritized Deadline Scheduling Algorithm (IPDSA) [11].

Pada penelitian ini, resource scheduling dengan algoritma resource scheduling IPDSA diimplementasikan dalam teknologi grid computing menggunakan PVM3 pada studi kasus parallel computing untuk mengetahui kemampuan dari algoritma tersebut dalam menyelesaikan permasalahan resource scheduling.

\section{Metode Penelitian}

Pada Gambar 1 digambarkan proses jalannya program pada tahap pengujian ini. Pertama dari komputerkomputer yang dijalankan, ada satu komputer yang berperan sebagai master, yang bertugas untuk menjadwalkan task, menerima tasks dan membagi task tersebut untuk host lainnya yang berperan sebagai slave. Host yang berperan sebagai slave memiliki tugas untuk list yang dihimpun sebagai resource untuk memproses job dan jumlah dari elemen pemrosesan digunakan untuk desain sistem tertentu. Time Delay mengalokasikan resource dari task yang merupakan perbedaan antara waktu eksekusi yang diharapkan dan deadline dari task yang dijalankan. Kebutuhan dari task mengenai tipe properti apa yang diinginkan sebagai resource dan berapa banyak prosesor yang diperlukan untuk melaksanakan task tersebut maka dibuatlah daftar dari resource untuk task yang dijalankan. Pemilihan yang tepat dilakukan berdasarkan kecepatan pemrosesan untuk task-task yang terdaftar. Prioritas diberikan kepada resource yang memiliki kecepatan pemrosesan maksimum untuk melaksanakan tugas sebelumnya.

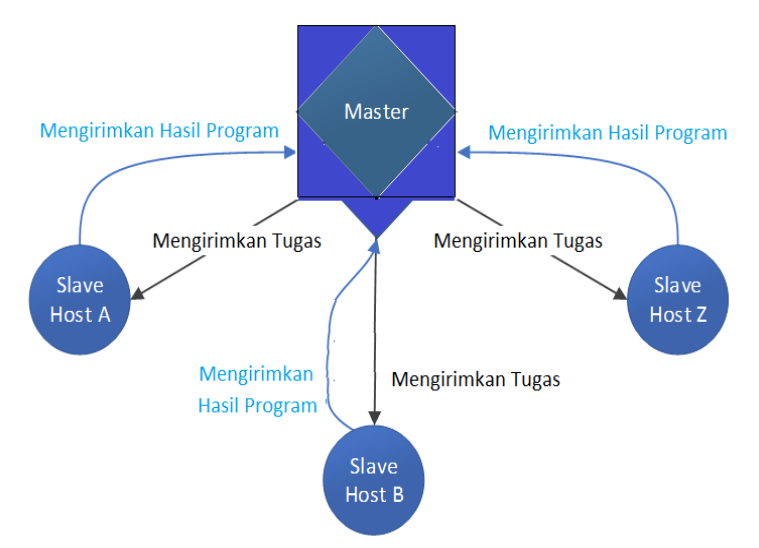

Gambar 1. Ilustrasi Pengujian Implementasi Program 
Algoritma resource scheduling IPDSA memiliki time delay paling sedikit untuk dieksekusi. mengelompokkan task sesuai yang dijelaskan di atas Akhirnya, finish time dan tardiness dari setiap task dengan menggunakan nilai Time Delay yang merupakan didapatkan. Langkah-langkah algoritma resource perbedaan antara deadline yang diberikan kepada scheduling IPDSA [11], dapat ditunjukkan pada sebuah task dengan waktu eksekusi yang diharapkan algoritma:

dari task tersebut. Nilai Time Delay tersebut diperoleh dari persamaan (1).

$$
T D_{i}=d_{i}-E T_{i}
$$

Dimana $d_{i}$ merupakan nilai deadline pada task $i$, dan $E T_{i}$ Output: Finish Time, Time Delay, Average merupakan Expected Execution Time pada satu kali proses program dijalankan. Kemudian menghitung Total Tardiness yang merupakan penjumlahan dari tardiness untuk setiap task dan membaginya dengan jumlah total task, lalu didapatkan average tardiness, yang diberikan oleh persamaan (2).

$$
A T R=\frac{\sum_{i=1}^{n} T R_{i}}{n}
$$

Dimana $\mathrm{ATR}_{\mathrm{i}}$ (average tardiness) yaitu rata - rata tardiness pada pada setiap task $i$ yang dijalankan dalam satu kali proses program dijalankan, $T R_{i}$ adalah nilai Tardiness dan $\mathrm{n}$ adalah banyaknya task yang dijalankan dalam satu kali proses program dijalankan. Sedangkan Tardiness (TR) merupakan waktu yang tertunda antara deadline task dan waktu selesai task tersebut. Nilai Tardiness tersebut didapatkan dari persamaan (3).

$$
A L M_{i}=\frac{1}{m} \sum_{i=1}^{m} A L C_{i}
$$

Dimana ALMi (average load machine system) yaitu rata - rata load pada level machine, ALCi (average load cluster) yaitu rata - rata load pada setiap cluster, dan $\mathrm{m}$ adalah banyaknya cluster pada suatu sistem di level machine. Nilai ALCi didapatkan dari persamaan (4).

$$
T R_{i}=d_{i}-F_{i}
$$

Dimana $d_{i}$ merupakan nilai deadline pada task $i$, dan $F_{i}$ merupakan Finish Time pada setiap task $i$ yang dijalankan dalam satu kali proses program dijalankan. Kemudian parameter yang perlu diperhatikan adalah Non-delayed tasks yang merupakan jumlah dari task yang waktu penyelesaiannya kurang dari deadline task tersebut atau dapat diartikan sebagai "Total jumlah task yang diselesaikan sebelum deadline”.

Pada algoritma ini parameter yang dibutuhkan antara lain: taskID, expected execution time, deadline dan number of host. Time delay untuk setiap task dihitung menggunakan persamaan (1). Task pada antrian yang telah siap disusun secara ascending berdasarkan pada computed time delay dari setiap task. Jika task memiliki computed time delay yang sama, maka task tersebut harus disusun berdasarkan metode First Come First Serve (FCFS) untuk setiap antrian yang telah siap. Kemudian mengurutkan task berdasarkan time delay pada urutan secara ascending (task dengan time delay paling sedikit diberikan prioritas) dan memilih task yang

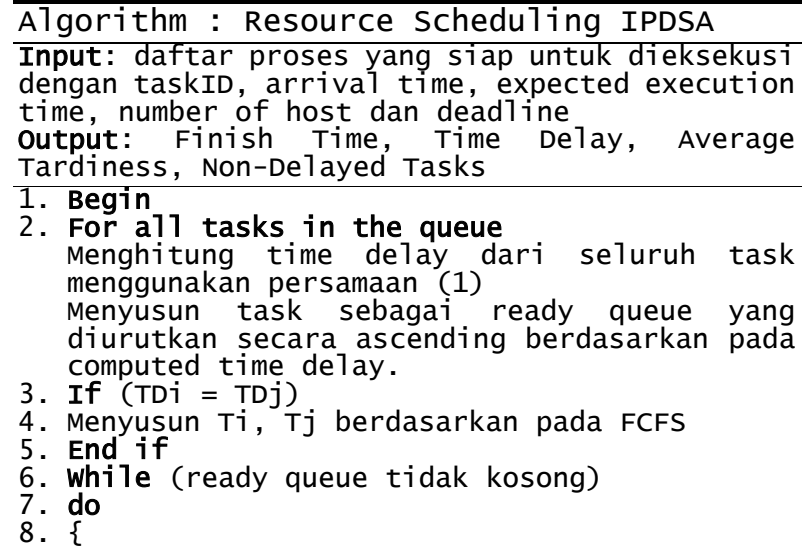

Menampilkan daftar prosesor yang sesuai untuk task tersebut

10. Memi 1ih prosesor dengan kecepatan pemrosesan terbaik di antara prosesor yang sesuai

11. Menjalankan task sesuai dengan computationa 1 length

12. Menghitung nilai Finising Time (Fi) dari task

13. Menghitung nilai Tardiness menggunakan persamaan (3)

14.If (di $>\mathrm{Fi})$

15. Then

16. Increment the Non-Delayed job counter

17. End if

18.

19. Menghitung average tardiness menggunakan persamaan (2)

\subsection{Parallel Virtual Machine versi 3 (PVM3)}

PVM3 atau Parallel Virtual Machine version 3 adalah seperangkat alat dan library perangkat lunak terintegrasi yang mengemulsikan kerangka kerja konkuren yang pertujuan umum, fleksibel, dan heterogen pada komputer yang saling berhubung dengan beragam arsitektur [12,13]. Secara singkat, prinsip-prinsip yang mendasari PVM3 meliputi:

1. User-configured host pool, Tugas komputasi aplikasi dijalankan pada serangkaian mesin yang dipilih oleh pengguna untuk menjalankan program PVM3 tertentu. Baik mesin CPU tunggal dan multiprosesor perangkat keras (termasuk komputer memori bersama dan memori terdistribusi) dapat menjadi bagian dari kumpulan host. Host pool dapat diubah dengan menambah dan menghapus mesin selama operasi (fitur penting untuk toleransi kesalahan).

2. Translucent access to hardware, Program aplikasi dapat memandang lingkungan perangkat keras sebagai kumpulan elemen pemrosesan virtual yang tidak dapat dikaitkan atau dapat memilih untuk mengeksploitasi kemampuan mesin tertentu di kumpulan host dengan memposisikan tugas komputasi tertentu pada komputer yang paling tepat. 
3. Process-based computation, Unit paralelisme dalam 3.1. Grid Environment

PVM adalah task, sebuah rangkaian kontrol berurutan independen yang berganti-ganti antara komunikasi dan komputasi. Tidak ada pemetaan proses-ke-prosesor yang tersirat atau ditegakkan oleh PVM; khususnya, banyak tugas dapat dijalankan pada satu prosesor.

Algoritma IPDSA diimplementasikan pada percobaan ini dilakukan menggunakan 40 komputer yang berada di Laboratorium Komputer S1 Informatika Universitas Sebelas Maret. 40 komputer tersebut dioperasikan menggunakan sistem operasi Ubuntu 18.04.4 LTS (Long Term Support) yang ter-install native menggunakan

4. Explicit message-passing model, Kumpulan tugas desktop environment GNOME (GNU Network Object komputasi, masing-masing melakukan bagian dari Model Environment). Spesifikasi komputer yang workload aplikasi menggunakan data-, fungsional-, digunakan yaitu CPU 64-bit, RAM 8 GB, Harddisk 1 atau dekomposisi hibrid, bekerja sama dengan secara TB, dengan sistem operasi Ubuntu 18.04.4 LTS. eksplisit mengirim dan menerima pesan satu sama Konfigurasi jaringan dalam pengujian ini menggunakan lain. Ukuran pesan hanya dibatasi oleh jumlah network interface setiap unit komputer dan terkoneksi memori yang tersedia. antar komputer secara lokal.

5. Heterogeneity support, Sistem PVM mendukung 3.2. Hasil Percobaan Implementasi Program heterogenitas dalam hal mesin, jaringan, dan aplikasi. Sehubungan dengan pengiriman pesan, PVM memungkinkan pesan yang mengandung lebih dari satu tipe data untuk dipertukarkan antara mesin yang memiliki representasi data berbeda.

Pada percobaan tahap ini yaitu menguji Algoritma Scheduling IPDSA menggunakan 1 program dengan variasi jumlah task dan variasi jumlah host yang terhubung. Program yang dijalanakan berupa program yang melakukan proses generator 100.000 angka secara

6. Multiprocessor support, PVM menggunakan acak, lalu angka-angka tersebut diurutkan menggunakan fasilitas native message-passing pada multi-prosesor algoritma sorting Bubble Sort. Pada tahap ini, hasil untuk mengambil keuntungan dari perangkat keras percobaan diukur menggunakan Expected Execution yang mendasarinya. Vendor sering menyediakan Time, Deadline, Time Delay, Finishing Time, Tardiness, PVM mereka sendiri yang dioptimalkan untuk nilai Average Tardiness dan nilai Non-Delayed Job. sistem mereka, yang masih dapat berkomunikasi dengan versi PVM publik.

Tabel 1 menunjukkan jumlah ATR, jumlah NDT dan persentase NDT dari task yang dijalankan untuk satu kali

Sistem PVM terdiri dari dua bagian. Bagian pertama proses dengan 7 host. Percobaan dilakukan sebanyak 5 adalah daemon, yang disebut pvmd3 dan kadang-kadang kali proses yang dijalankan pada satu kali eksekusi disingkat pvmd, yang berada di semua komputer yang program. Tabel 2 menunjukkan jumlah ATR, jumlah membentuk virtual machine. Pvmd3 dirancang setiap NDT dan persentase NDT dari task yang dijalankan user dengan login yang valid dapat menginstal daemon untuk satu kali proses dengan 15 host. Percobaan ini pada mesin. Ketika user menjalankan aplikasi PVM, dilakukan sebanyak 5 kali proses yang dijalankan pada ia pertama kali menciptakan virtual machine dengan satu kali eksekusi program. Demikian juga untuk Tabel memulai PVM. Aplikasi PVM kemudian dapat dimulai 3 dengan 33 host dan Tabel 4 dengan 40 host.

dari prompt (command promt atau terminal) Unix pada host manapun. Beberapa user dapat mengonfigurasi virtual machine yang tumpang tindih, dan setiap user dapat menjalankan beberapa aplikasi PVM secara bersamaan.

Bagian kedua dari sistem adalah library dari PVM interface routines. Ini berisi functionally complete penelitian ini dimodifikasi menggunakan PVM3. Pada reporoire of primitives yang diperlukan kerja sama hasil pengujian menunjukkan, bahwa dalam antara task aplikasi. Library ini berisi routines yang menjalankan algoritma resource scheduling memiliki 3
dapat dipanggil user untuk pemindahan message, kriteria. dapat dipanggil user untuk pemindahan message, kriteria.

spawning process, koordinasi tasks, dan modifikasi virtual machine.

\section{Hasil dan Pembahasan}

Bagian ini membahas hasil percobaan implementasi algoritma resource scheduling IPDSA menggunakan PVM3 pada Grid Environment.

Berdasarkan hasil pengujian program diperoleh hasil pada Tabel 1, Tabel 2, Tabel 3 dan Tabel 4, terdapat improvisasi terhadap metode penjadwalan algoritma task scheduling IPDSA yaitu pada environment yang digunakan, dimana pada penelitian sebelumnya menggunakan GridSim maupun CloudSim lalu pada penelitian ini dimodifikasi menggunakan PVM3. Pada 


\begin{tabular}{|c|c|c|c|c|c|}
\hline $\mathbf{5}$ & 2 & 1000 & 21250,30 & 987 & $98,700 \%$ \\
\hline $\mathbf{6}$ & & 2000 & 21841,76 & 1991 & $99,550 \%$ \\
\hline $\mathbf{7}$ & & 3000 & 17753,47 & 2981 & $99,367 \%$ \\
\hline $\mathbf{8}$ & & 4000 & 19393,60 & 3964 & $99,100 \%$ \\
\hline $\mathbf{9}$ & 3 & 1000 & 17590,15 & 969 & $96,900 \%$ \\
\hline $\mathbf{1 0}$ & & 2000 & 19160,68 & 1979 & $98,950 \%$ \\
\hline $\mathbf{1 1}$ & & 3000 & 19575,62 & 2973 & $99,100 \%$ \\
\hline $\mathbf{1 2}$ & & 4000 & 19651,25 & 3971 & $99,275 \%$ \\
\hline $\mathbf{1 3}$ & 4 & 1000 & 21653,23 & 987 & $98,700 \%$ \\
\hline $\mathbf{1 4}$ & & 2000 & 185549,14 & 2000 & $100,000 \%$ \\
\hline $\mathbf{1 5}$ & & 3000 & 21425,12 & 2976 & $99,200 \%$ \\
\hline $\mathbf{1 6}$ & & 4000 & 19509,29 & 3974 & $99,350 \%$ \\
\hline $\mathbf{1 7}$ & 5 & 1000 & 19353,84 & 982 & $98,200 \%$ \\
\hline $\mathbf{1 8}$ & & 2000 & 16782,18 & 1970 & $98,500 \%$ \\
\hline $\mathbf{1 9}$ & & 3000 & 188551,11 & 2999 & $99,967 \%$ \\
\hline $\mathbf{2 0}$ & & 4000 & 20594,01 & 3960 & $99,000 \%$ \\
\hline
\end{tabular}

\begin{tabular}{|c|c|c|c|c|c|}
\hline $\mathbf{5}$ & 2 & 1000 & 15388,99 & 973 & $97,300 \%$ \\
\hline $\mathbf{6}$ & & 2000 & 17770,56 & 1975 & $98,750 \%$ \\
\hline $\mathbf{7}$ & & 3000 & 17907,23 & 2970 & $99,000 \%$ \\
\hline $\mathbf{8}$ & & 4000 & 19299,30 & 3953 & $98,825 \%$ \\
\hline $\mathbf{9}$ & 3 & 1000 & 19727,10 & 977 & $97,700 \%$ \\
\hline $\mathbf{1 0}$ & & 2000 & 20130,09 & 1981 & $99,050 \%$ \\
\hline $\mathbf{1 1}$ & & 3000 & 22695,10 & 2988 & $99,600 \%$ \\
\hline $\mathbf{1 2}$ & & 4000 & 18865,52 & 3960 & $99,000 \%$ \\
\hline $\mathbf{1 3}$ & 4 & 1000 & 19489,30 & 984 & $98,400 \%$ \\
\hline $\mathbf{1 4}$ & & 2000 & 16137,84 & 1976 & $98,800 \%$ \\
\hline $\mathbf{1 5}$ & & 3000 & 18481,45 & 2976 & $99,200 \%$ \\
\hline $\mathbf{1 6}$ & & 4000 & 163404,09 & 4000 & $100,000 \%$ \\
\hline $\mathbf{1 7}$ & 5 & 1000 & 22957,76 & 992 & $99,200 \%$ \\
\hline $\mathbf{1 8}$ & & 2000 & 13884,84 & 1954 & $97,700 \%$ \\
\hline $\mathbf{1 9}$ & & 3000 & 16736,78 & 2842 & $94,733 \%$ \\
\hline $\mathbf{2 0}$ & & 4000 & 21091,60 & 3972 & $99,300 \%$ \\
\hline
\end{tabular}

Tabel 2. Hasil Percobaan dengan 15 Host

\begin{tabular}{|l|l|l|l|l|l|}
\hline No & $\begin{array}{c}\text { Uji } \\
\text { ke- }\end{array}$ & $\begin{array}{l}\text { Jumlah } \\
\text { Task }\end{array}$ & ATR (ms) & $\begin{array}{l}\text { Jumlah } \\
\text { NDT }\end{array}$ & NDT \\
\hline $\mathbf{1}$ & 1 & 1000 & 20508,93 & 980 & $98,000 \%$ \\
\hline $\mathbf{2}$ & & 2000 & 17556,10 & 1960 & $98,000 \%$ \\
\hline $\mathbf{3}$ & & 3000 & 21903,55 & 2987 & $99,567 \%$ \\
\hline $\mathbf{4}$ & & 4000 & 17785,73 & 3952 & $98,800 \%$ \\
\hline $\mathbf{5}$ & 2 & 1000 & 19723,05 & 990 & $99,000 \%$ \\
\hline $\mathbf{6}$ & & 2000 & 18961,75 & 1987 & $99,350 \%$ \\
\hline $\mathbf{7}$ & & 3000 & 19010,31 & 2975 & $99,167 \%$ \\
\hline $\mathbf{8}$ & & 4000 & 17320,19 & 3955 & $98,875 \%$ \\
\hline $\mathbf{9}$ & 3 & 1000 & 22986,59 & 987 & $98,700 \%$ \\
\hline $\mathbf{1 0}$ & & 2000 & 18678,41 & 1978 & $98,900 \%$ \\
\hline $\mathbf{1 1}$ & & 3000 & 15693,97 & 2967 & $98,900 \%$ \\
\hline $\mathbf{1 2}$ & & 4000 & 17951,24 & 3941 & $98,525 \%$ \\
\hline $\mathbf{1 3}$ & 4 & 1000 & 19790,07 & 994 & $99,400 \%$ \\
\hline $\mathbf{1 4}$ & & 2000 & 19568,10 & 1979 & $98,950 \%$ \\
\hline $\mathbf{1 5}$ & & 3000 & 22923,81 & 2988 & $99,600 \%$ \\
\hline $\mathbf{1 6}$ & & 4000 & 18289,47 & 3941 & $98,525 \%$ \\
\hline $\mathbf{1 7}$ & 5 & 1000 & 18159,54 & 985 & $98,500 \%$ \\
\hline $\mathbf{1 8}$ & & 2000 & 19194,18 & 1977 & $98,850 \%$ \\
\hline $\mathbf{1 9}$ & & 3000 & 166838,36 & 3000 & $100,000 \%$ \\
\hline $\mathbf{2 0}$ & & 4000 & 18764,55 & 3964 & $99,100 \%$ \\
\hline & & & & & \\
\hline
\end{tabular}

Tabel 4.Hasil Percobaan dengan 40 Host

\begin{tabular}{|c|c|c|c|c|c|}
\hline No & $\begin{array}{c}\text { Uji } \\
\text { ke- }\end{array}$ & $\begin{array}{c}\text { Jumlah } \\
\text { Task }\end{array}$ & $\begin{array}{c}\text { ATR } \\
(\mathbf{m s})\end{array}$ & $\begin{array}{c}\text { Jumlah } \\
\text { NDT }\end{array}$ & NDT \\
\hline $\mathbf{1}$ & 1 & 1000 & 19624,42 & 988 & $98,800 \%$ \\
\hline $\mathbf{2}$ & & 2000 & 17363,25 & 1969 & $98,450 \%$ \\
\hline $\mathbf{3}$ & & 3000 & 17834,10 & 2957 & $98,567 \%$ \\
\hline $\mathbf{4}$ & & 4000 & 22266,70 & 3984 & $99,600 \%$ \\
\hline $\mathbf{5}$ & 2 & 1000 & 21462,58 & 988 & $98,800 \%$ \\
\hline $\mathbf{6}$ & & 2000 & 20102,87 & 1974 & $98,700 \%$ \\
\hline $\mathbf{7}$ & & 3000 & 19949,54 & 2967 & $98,900 \%$ \\
\hline $\mathbf{8}$ & & 4000 & 19252,97 & 3973 & $99,325 \%$ \\
\hline $\mathbf{9}$ & 3 & 1000 & 22151,54 & 983 & $98,300 \%$ \\
\hline $\mathbf{1 0}$ & & 2000 & 15640,64 & 1964 & $98,200 \%$ \\
\hline $\mathbf{1 1}$ & & 3000 & 20839,90 & 2955 & $98,500 \%$ \\
\hline $\mathbf{1 2}$ & & 4000 & 17375,90 & 3952 & $98,800 \%$ \\
\hline $\mathbf{1 3}$ & 4 & 1000 & 22706,54 & 991 & $99,100 \%$ \\
\hline $\mathbf{1 4}$ & & 2000 & 16740,59 & 1968 & $98,400 \%$ \\
\hline $\mathbf{1 5}$ & & 3000 & 16687,57 & 2929 & $97,633 \%$ \\
\hline $\mathbf{1 6}$ & & 4000 & 16534,43 & 3929 & $98,225 \%$ \\
\hline $\mathbf{1 7}$ & 5 & 1000 & 17746,71 & 983 & $98,300 \%$ \\
\hline $\mathbf{1 8}$ & & 2000 & 20064,67 & 1982 & $99,100 \%$ \\
\hline $\mathbf{1 9}$ & & 3000 & 20162,91 & 2965 & $98,833 \%$ \\
\hline $\mathbf{2 0}$ & & 4000 & 15514,09 & 3925 & $98,125 \%$ \\
\hline & & & & & \\
\hline
\end{tabular}

Tabel 3. Hasil Percobaan dengan 33 Host

\begin{tabular}{|c|c|c|c|c|c|}
\hline No. & $\begin{array}{c}\text { Uji } \\
\text { ke- }\end{array}$ & $\begin{array}{c}\text { Jumlah } \\
\text { Task }\end{array}$ & ATR (ms) & $\begin{array}{c}\text { Jumlah } \\
\text { NDT }\end{array}$ & NDT \\
\hline $\mathbf{1}$ & 1 & 1000 & 21310,73 & 985 & $98,500 \%$ \\
\hline $\mathbf{2}$ & & 2000 & 19007,21 & 1979 & $98,950 \%$ \\
\hline $\mathbf{3}$ & & 3000 & 19906,53 & 2972 & $99,067 \%$ \\
\hline $\mathbf{4}$ & & 4000 & 22621,65 & 3975 & $99,375 \%$ \\
\hline
\end{tabular}

Jurnal RESTI (Rekayasa Sistem dan Teknologi Informasi) Vol. 4 No. 5 (2020) 957 - 963 


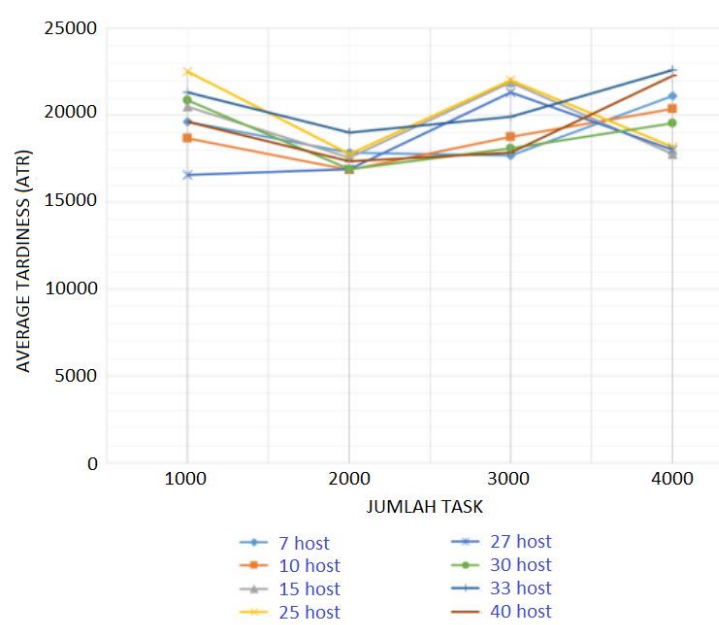

Gambar 2. Grafik Average Tardiness (ATR) dengan Jumlah Task

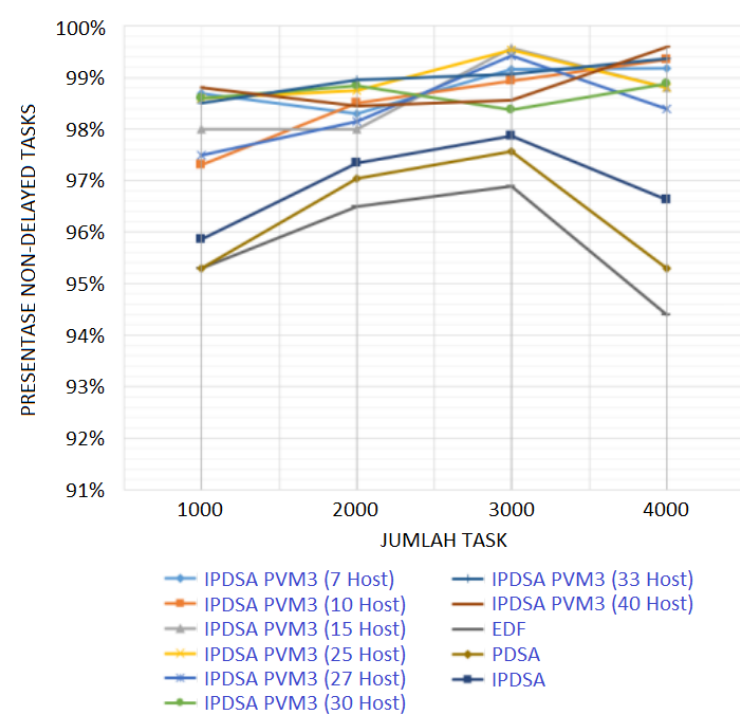

Gambar 3. Grafik Non-Delayed Task dengan Jumlah Task

Kriteria pertama, task dijalankan berdasarkan prioritas yang telah diberikan yaitu Prioritas 1, Prioritas 2 dan Prioritas 3, jumlah task yang masuk kedalam golongan prioritas tersebut didapatkan dari parameter nilai Time Delay (TD), antrian task diurutkan secara ascending berdasarkan nilai TD pada masing-masing task, pengelompokan task untuk setiap kelompok prioritas didapatkan dari nilai rentang tiap golongan prioritas dalam satu kali program berjalan. Beberapa hasil percobaan menunjukkan pengelompokkan prioritas task yang tidak wajar berupa kelompok prioritas task yang memiliki 0 task, hal ini disebabkan oleh faktor yang lain seperti koneksi jaringan yang tidak stabil sehingga terjadi bottle neck pada jaringan yang digunakan, dan dapat disebabkan oleh proses-proses yang lain yang berjalan di latar belakang sistem operasi.

Kriteria kedua, Average Tardiness (ATR) yang didapatkan pada percobaan menggunakan PVM3 ini menunjukkan nilai yang stabil, karena PVM3 dapat menggunakan sumber daya yang dapat terdistribusi secara optimal dengan jumlah komputer (host) yang terhubung dengan PVM3 pada setiap kelompok berbeda-beda [14]. Pada setiap percobaan yang dilakukan pada penelitian ini memiliki jumlah host yang beragam, yaitu 7 host, 10 host, 15 host, 25 host, 27 host, 30 host, 33 host dan 40 host, meskipun jumlah dan spesifikasi sumber daya yang heterogen dan dalam kondisi yang berbeda sebagaimana Gambar 2 dan Gambar 3. Oleh karena itu, PVM3 memungkinan kumpulan komputer (host) heterogen berfungsi sebagai mesin paralel kinerja tinggi tunggal (virtual), melalui mesin virtualnya ini memiliki daemon yang berjalan di semua komputer yang membentuk mesin virtual. PVM3 memiliki sifat portabilitas, heterogenitas dan juga memungkinkan untuk mengatasi kesalahan komunikasi antar komputer.

Kriteria ketiga, jumlah task yang tidak tertunda atau Non-Delayed Task (NDT) memiliki nilai diatas 97,3\% dari total task yang dijalankan. Persentase NDT yang didapatkan pada percobaan menggunakan PVM3 lebih tinggi dibandingkan dengan penelitian sebelumnya yaitu pada garis EDF, PDSA dan IPDSA, karena task dijalankan berdasarkan prioritas yang telah diberikan, nilai Time Delay yang didapatkan dan penggunaan PVM3 memungkinkan integrasi multi-prosesor antara komputer-komputer dalam satu jaringan yang saling terhubung [9].

\section{Kesimpulan}

Algoritma resource scheduling IPDSA telah berhasil diimplementasikan pada grid environment, yaitu mengunggnakan beberapa komputer sebagai Grid Resource. Percobaan yang dilakukan dengan memvariasikan jumlah task sebanyak 1000, 2000, 3000 dan 4000. Algoritma scheduling IPDSA diimplementasikan menggunakan PVM3, yang mampu memberikan performa Grid Resource yang optimal ketika digunakan untuk menyelesaikan task yang ditugaskan. Untuk menugaskan task mana yang dieksekusi, algoritma scheduling IPDSA memilih task yang memiliki nilai time delay minimum lalu task dikirimkan ke host yang dituju. Algoritma scheduling IPDSA juga berhasil dioptimalkan dengan memberikan nilai prioritas pada setiap task yang ditugaskan untuk satu kali proses penjalanan program. Hal ini ditunjukkan dengan nilai rata-rata keterlambatan (Average Tardiness/ATR) yang stabil dalam mengerjakan task, dan persentase Non-Delayed Task yang tinggi dibanding dengan penelitian sebelumnya yaitu memiliki nilai diatas $97,3 \%$ dari total task yang dijalankan. Indikator performa Average Tardiness (ATR) dan Non-Delayed Task (NDT) digunakan untuk tujuan perbandingan.

\section{Daftar Rujukan}

[1] Foster, Kesselman, C. and Tuecke, S., 2001, The anatomy of the grid: Enabling scalable virtual organizations, Int. J. High Perform. Comput. Appl., vol. 15, no. 3, pp. 200-222.

2] Goswami, S. and De Sarkar, A., 2013, A comparative study of load balancing algorithms in computational grid environment, in 
2013 Fifth International Conference on Computational Intelligence, Modelling and Simulation, pp. 99-104.

[3] Matani, A., Naji, H.R. and Motallebi, H., 2020, A Fault-Tolerant Workflow Scheduling Algorithm for Grid with Near-Optimal Redundancy, Journal of Grid Computing, volume 18, pp. 377-394

[4] Patel, D. K., Tripathy, D. and Tripathy, C. R., 2016, Survey of load balancing techniques for grid, J. Netw. Comput. Appl., vol. 65, pp. 103-119

[5] Balasangameshwara, J. and Raju, N., 2012, Performance-driven load balancing with a primary-backup approach for computational grids with low communication cost and replication cost, IEEE Trans. Comput., vol. 62, no. 5, pp. 990-1003

[6] Midya, S., Roy, A., Majumder, K. and Phadikar, S., 2018, Multiobjective optimization technique for resource allocation and task scheduling in vehicular cloud architecture: A hybrid adaptive nature inspired approach, Journal of Network and Computer Applications, Volume 103, 1 February 2018, pp. 58-84, https://doi.org/10.1016/j.jnca.2017.11.016

[7] Topcuoglu, H., Hariri, S., and Wu, M., 2002, Performanceeffective and low-complexity task scheduling for heterogeneous computing. IEEE Transactions Parallel Distribution Systems 13(3), pp. 260-274

[8] Kumar, M., Sharma, S. C., Goel, A. and Singh, S. P., 2019, A comprehensive survey for scheduling techniques in cloud computing, J. Netw. Comput. Appl..
[9] Hao, Y., Liu, G. and Wen, N., 2012, An enhanced load balancing mechanism based on deadline control on GridSim, Future Gener. Comput. Syst., vol. 28, no. 4, pp. 657-665

10]Xu, Z., Hou, X. and Sun, J., 2003, Ant algorithm-based task scheduling in grid computing, in CCECE 2003-Canadian Conference on Electrical and Computer Engineering. Toward a Caring and Humane Technology (Cat. No. 03CH37436), vol. 2, pp. 1107-1110.

11]Chauhan, A., Singh, S., Negi, S. and Verma, S. K., 2016, Algorithm for deadline based task scheduling in heterogeneous grid environment, in 2016 2nd International Conference on Next Generation Computing Technologies (NGCT), pp. 219-222.

[12] Geist, A., Beguelin, A., Dongarra, J., Jiang, W., Manchek, R. and Sunderam, V. S., 1994, PVM: Parallel Virtual Machine :a Users' Guide and Tutorial for Networked Parallel Computing. MIT Press.

[13]Nanthiya, D. and Keerthika, P., 2013, Load balancing GridSim architecture with fault tolerance, in 2013 International Conference on Information Communication and Embedded Systems (ICICES), pp. 425-428

[14] Sampath S., Nanjesh B. R., Sagar, B. B. and Subbaraya, C. K., 2014, Performance optimization of PVM based parallel applications using optimal number of slaves, in 2014 International Conference on Reliability Optimization and Information Technology (ICROIT), Feb. 2014, pp. 388-392, doi: 10.1109/ICROIT.2014.6798360. 